\title{
Article \\ Food Behavior in Emergency Time: Wild Plant Use for Human Nutrition during the Conflict in Syria
}

\author{
Naji Sulaiman ${ }^{1}\left(\mathbb{D}\right.$, Andrea Pieroni ${ }^{2,3}\left[\right.$, Renata Sõukand ${ }^{4}(\mathbb{D}$ and Zbynek Polesny $1, * \mathbb{C}$ \\ 1 Department of Crop Sciences and Agroforestry, Faculty of Tropical AgriSciences, Czech University of Life \\ Sciences Prague, Kamýcká 129, 16500 Praha-Suchdol, Czech Republic; sulaimann@ftz.czu.cz \\ 2 University of Gastronomic Sciences, Piazza Vittorio Emanuele II, 9, 12042 Pollenzo, Italy; a.pieroni@unisg.it \\ 3 Medical Analysis Department, Faculty of Science, Tishk International University, Erbil 44001, Iraq \\ 4 Department of Environmental Sciences, Informatics and Statistics, Ca' Foscari University of Venice, \\ Via Torino 155, 30174 Venezia, Italy; renata.soukand@unive.it \\ * Correspondence: polesny@ftz.czu.cz
}

check for updates

Citation: Sulaiman, N.; Pieroni, A.; Sõukand, R.; Polesny, Z. Food Behavior in Emergency Time: Wild Plant Use for Human Nutrition during the Conflict in Syria. Foods 2022, 11, 177. https://doi.org/ 10.3390 /foods 11020177

Academic Editor: Giancarlo Statti

Received: 12 December 2021

Accepted: 31 December 2021

Published: 10 January 2022

Publisher's Note: MDPI stays neutral with regard to jurisdictional claims in published maps and institutional affiliations.

Copyright: (C) 2022 by the authors. Licensee MDPI, Basel, Switzerland. This article is an open access article distributed under the terms and conditions of the Creative Commons Attribution (CC BY) license (https:// creativecommons.org/licenses/by/ $4.0 /)$.

\begin{abstract}
Wild food plants (WFPs) have been an important source of human nutrition since ancient times, and it particularly revives when conventional food is not available due to emergency situations, such as natural disasters and conflicts. The war in Syria has entered 10 years since it started in 2011, and it has caused the largest war-related crises since World War II. Nearly $60 \%$ of the Syrian population (12.4 million people) are food-insecure. WFPs are already culturally important in the region, and may be supplementing local diets during this conflict. Our study aimed to uncover the conflict's effect on the use of WFPs and to know what species are consumed by local people during the current crisis. The fieldwork was carried out between March 2020 and March 2021 in the Tartus governorate located in the coastal region of Syria. Semi-structured interviews were conducted with 50 participants ( 26 women and 24 men) distributed in 26 villages along the study area. We recorded the vernacular names, uses, plant parts used, modes of preparation and consumption, change in WFP use before and during the conflict, and informants' perceptions towards WFPs. We documented 75 wild food plant species used for food and drink. Almost two-thirds (64\%) of informants reported an increase in their reliance on wild plants as a food source during the conflict. The species of Origanum syriacum, Rhus coriaria, Eryngium creticum, and Cichorium intybus were among the most quoted species by informants. Sleeq (steamed leafy vegetables), Zaatar (breakfast/dinner food), and Louf (soup) were the most popular wild plant-based dishes.
\end{abstract}

Keywords: Eastern Mediterranean; emergency human behavior; ethnobotany; Sleeq; traditional food; Zaatar

\section{Introduction}

Food is located at the bottom of Maslow's hierarchy of human needs, where any threat to these basic needs could impact human behavior and bring emergency reactions [1] Despite the importance of food, hunger remains a main part of human history, as well as the present. According to FAO [2] estimations, the number of hungry people will exceed 840 million by 2030 . On the other hand, two billion people $(25.9 \%$ of the global population) experienced hunger or did not have regular access to nutritious and sufficient food in 2019. Much of the recent increase in food insecurity can be attributed to the greater number of conflicts and climate change impacts [2]. In general, wartime is characterized by deterioration of life quality, as wars often lead to mass human migrations, armed-conflict zones, and economic crises. Conflict areas lack basic living necessities, such as appropriate shelter, drinking water, and medicine. Furthermore, sufficient and diverse food sources are scarce, while hunger and nutritional deficiency-related diseases are widespread [3].

Since ethnobotany has been described as the science of survival [4], its importance increases during armed conflicts. In crises where conventional food is not available, people 
turn to their traditional ecological knowledge to secure their needs from the surrounding environment, where wild plants serve as the main food source. Generally, the use of wild plants as an emergency food supply has been present throughout the entire history of humankind [5]; gathered plants from the wild have been used to cope with food shortages in many regions around the globe [6,7], as well as to alleviate poverty levels [8]. Several studies have highlighted wild plant use and its importance for human survival in times of conflicts, particularly in Bosnia and Herzegovina during the Balkan War $[3,9,10]$, as well as in the Netherlands with the food famine during World War II [11].

In the last two decades, the world experienced an increase in its number of conflicts. Only between 2000 and 2014, there was an average of 35 active conflicts every year around the globe [12]. Since the so-called "Arabic Spring" started in the Middle East a decade ago, many countries have fallen into civil wars, local conflicts, and economic crises. In March 2011, Syria entered an armed conflict that caused the largest displacement crisis since World War II. So far, 6.2 million Syrians are internally displaced, and 5.7 million are registered as refugees outside of the country. Soaring food and fuel prices, stagnant salaries, loss of livelihoods, and reduced food production have led to widespread food insecurity across Syria [13]. Nearly $60 \%$ of the Syrian population (12.4 million people) are food-insecure [14]. FAO [15] reported that wheat production is at less than $25 \%$ of pre-conflict levels, which has significantly affected food security in the country. Recent statistics from Syria show low dietary intake of several key foods and nutrients compared to the minimum recommended level, such as vegetables, which is at $25 \%$ less than the global level and almost $50 \%$ less than the theoretical minimum-risk exposure level [16]. The economic conditions resulting from the ongoing conflict are not only affecting the war battle areas, but being reflected across the country.

In Syria, as a part of the Mediterranean basin, cooked vegetables and salads made from wild greens have been particularly important as local traditional foods since ancient times [17]. However, wild food plants (WFPs) have not been widely studied in the Syrian context [18,19], and while teas prepared from wild plants have been marginally covered [20-22], there are no studies about the use of wild plants with a focus on the effects of the conflict. On the other hand, studies from surrounding countries, such as Lebanon [23,24], Cyprus [25], Iraqi-Kurdistan [26], Palestine [27], and Turkey [28] clearly show the importance of wild plants in the food culture of the East Mediterranean region. Similarly, the gathered plants from the wild have been a part of the Syrian local cuisine before the conflict and its associated economic crisis [19]. However, we hypothesize that the use of WFPs has changed during the ongoing conflict. Hence, the overall interest of our study was to uncover the conflict's effect on WFP use and to know what species are consumed by local people during the current crisis. We particularly aimed to conduct an inventory of the wild plant species used as food in the region, and to document the ethnobotanical knowledge, including modes of preparation and consumption, as well as to highlight the perceptions of local people toward use of WFPs both before and during the conflict. We also aimed to summarize the nutritional benefits of the most-reported WFPs.

\section{Materials and Methods}

\subsection{Study Area}

The study was conducted in the Tartus governorate (Figure 1), one of the 14 governorates of Syria. Initially, we aimed to include more than one governorate as a study area, but due to COVID-19 restrictions, the first author could not move beyond the Tartus Governorate. Tartus $\left(34.9^{\circ} \mathrm{N}\right.$ and $35.9^{\circ} \mathrm{E}$ ) is bordered by Lebanon in the south, Syrian governorates of Latakia in the north, and Homs and Hama in the east. Tartus forms roughly half of the Syrian Mediterranean coastline, extending to $183 \mathrm{~km} \mathrm{[29].} \mathrm{The} \mathrm{governorate}$ occupies a territory of $1896 \mathrm{~km}^{2}$ and has a population of 1,114,000 inhabitants [30]. The climate is Mediterranean, and characterized by hot and dry summers, moderate in the mountains, whereas winters are mild and wet. Average annual rainfall varies from 800 to $1000 \mathrm{~mm}$ [31]. The region has a long history that dates back to the era of Phoenicians 
who built several cities in the area, such as Arwad and Amrit. Arwad, the only inhabited island in the Eastern Mediterranean coastline, has been continuously occupied since at least the third millennium BC [32]. Tartus is a multi-ethnic and religious region consisting of Alawites, Sunnis, Ismailis, and Christians, with percentages of $69 \%, 18 \%, 7 \%$, and $6 \%$, respectively. Arabs are the majority in the governorate, with Greek and Turkmen minorities [33].

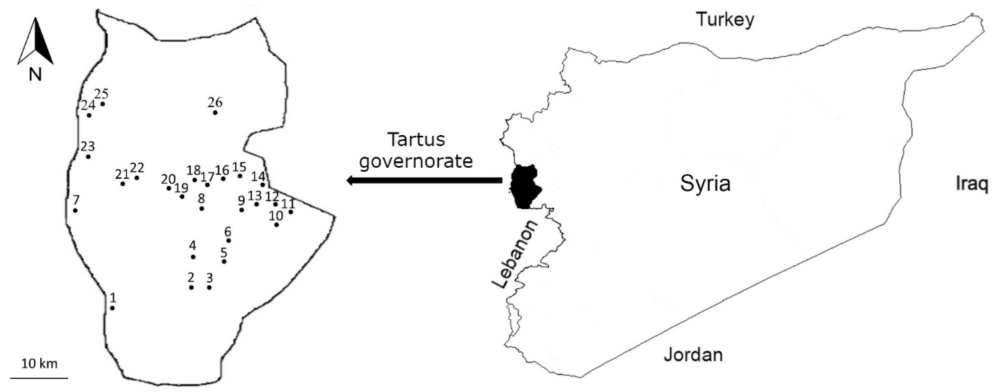

Figure 1. Study area map, the Tartus governorate and studied villages: 1. Al-Hamidiyah, 2. Ain Dabesh, 3. Al-Mitras, 4. Al-Sawma'a, 5. Bishrael, 6. Sibbeh, 7. Tartus, 8. Draykish, 9. Bait Yousef, 10. Husn Suleiman, 11. Annabi Saleh, 12. Annabi Matta, 13. Bestan Assouj, 14. Ain Dlaimah, 15. Fajlit, 16. Al-Tuffaha, 17. Kafr Tallesh, 18. Krafes, 19. Al-A'ujah, 20. Kawkab, 21. Bazughah, 22. Brmmanet Raad, 23. Maten Al-Sahel, 24. Al-Rawda, 25. Dahr Safra, 26. Sourani.

So far, the region has been relatively quiet and safe during the Syrian conflict. Tartus is entirely under the government control; however, it witnessed several security incidents [34]. It is facile to observe the lack of young men, since most of them were requested to join or taken to the Syrian army as a result of the ongoing war in other parts of the country. The unfinished conflict did not yet reveal the exact numbers of casualties and wounded young men of the governorate, which could exceed tens of thousands according to the local people. Tartus houses more than 169,000 displaced people from other Syrian governorates [35]. Although the study area is not significantly affected by war battles as other regions in Syria, the community is suffering from the side-effects of war, such as food shortage, economic sanctions, limited affordability of the market products, labour shortage, fuel insufficiency, frequent power outages, and general lack of agricultural production input [36,37]. Similarly to other governorates in Syria, around 50\% of households in the Tartus governorate had inadequate food consumption in the second half of 2020 [38].

\subsection{Fieldwork, Data Collection and Data Analysis}

The study was conducted between March 2020 and March 2021. The participants were chosen using a combination of purposive and convenient sampling methods $[39,40]$. We asked people in the village's streets if they would agree to be interviewed; the basic criteria for an informant to be selected was that he/she was a breadwinner and usually used wild plants for food or beverage. Semi-structured interviews were conducted with 50 participants ( 26 women and 24 men), aged between 25 and 97 years. Participants were chosen from 26 villages along the study area to include members from all religious and ethnic groups in the study.

Informants were asked to list all the wild plants they used for food and beverage preparation, their vernacular names, the parts used, and mode of preparation and consumption. Respondents were asked to report any changes in their use of WFPs prior to and during the conflict. Perceptions of informants towards WFPs were documented using open-ended questions, such as: Why do you use WFPs? Why were you using WFPs before the conflict started?

Verbal consent was always obtained before each interview, and the Code of Ethics of the International Society of Ethnobiology was followed [41]. A research permit was obtained from the General Commission for Scientific Agricultural Research and Tartus mu- 
nicipality (number: 9893; date: 5 April 2020). All interviews were conducted in the Arabic language. Plants were identified with the help of local taxonomists and the herbarium staff of the American University of Beirut, while nomenclature followed World Flora Online [42]. The collected voucher specimens were deposited in the Herbarium of the American University of Beirut (BEI). When the plant sample was not available, identification was done based on a detailed description of the plant and its habitat, as well as the local name(s) provided by the informants. Taxa that were not capable of being classified up to the species level were identified at the genus level. All local plant names were transcribed from the recorded local languages using the Latin alphabet.

Collected data were compared with previously published ethnobotanical studies from the Eastern Mediterranean region and adjacent countries [18,19,23-25,28,43], in order to determine differences and similarities in WFPs' uses. Data on the nutritional benefits of most reported species were obtained by reviewing the literature available online [44-54]. The relative importance of the reported plants was obtained by calculating the relative frequency of citation (RFC) for each species by dividing the number of informants mentioning the plant by the total number of informants. The RFC value ranged from 0 to 1 , with 0 as a theoretical value indicating that no informant mentioned the species, and 1 as the highest value indicating that all informants mentioned it [55].

\section{Results}

\subsection{Pre-Conflict vs. During-Conflict Use of Wild Food Plants}

The majority of our study respondents (94\%) used WFPs before the conflict, whereas $6 \%$ of them started to use those plants only after the conflict started a decade ago. Informants showed that WFPs have always been a part of their traditional diet. However, such meals served as complementary food before the conflict, while they became among one the main dishes in recent years. Almost two-thirds (64\%) of informants reported an increase in their reliance on wild plants as a source of food during the conflict compared to the pre-conflict time. On the other hand, 34\% of the informants reported a no-change status in their reliance, whereas $2 \%$ stated a decrease. The main reported reason behind the apparent increase of reliance on WFPs was the economic crisis that hit the whole country after the war, which affected the food prices and purchase power, while the reason for the minor percentage of decrease in reliance was the move from a rural to urban area. The conflict affected accessibility and WFP species selection; informants reported that during the conflict, they started to consume wild plant species that grew in anthropic sites and their surrounding orchards, such as Eryngium creticum and Malva sylvestris. On the other hand, species that grew in high mountains and remote areas, such as Gundelia tournefortii, witnessed a decrease in use during conflict years due to obstacles regarding movement and security concerns. According to our informants' statements, traditional knowledge of WFPs was noticeably decreasing during the stable economic situation in pre-conflict years. However, it was revived after becoming necessary to secure food during the conflict.

\subsection{Perceptions of Local People towards Wild Food Plants Pre and during the Conflict}

Informants' statements show a clear difference in perceptions and reasons for using WFPs during and before the conflict. The main motives behind the use of WFPs in the pre-conflict era were represented by the tendency to eat healthy and organic food, efforts to diversify the food and taste, and enjoyment of the activity of gathering plants from the wild. On the other hand, the difficulty to afford the market food products was the main reason for WFP use during the conflict. The majority of informants (58\%) reported that the natural ecosystems helped to substitute market products through the gathered plants, and consequently, to save money. The mutual perception among the local people was that some of the young generation's views on WFPs did not change during the conflict compared to the pre-conflict time. These young people, especially those who did not bear the responsibility of securing food for the household, perceived WFPs as non-prestigious food and felt ashamed to share information related to this food with their peers. 


\subsection{Diversity of the Wild Food Plants}

Our study documented 75 wild plant species used for food and beverage preparation by the local people. One taxon was identified only down to the genus level. The total of 75 taxa belonged to 70 genera and 28 botanical families. The most-represented families were Compositae (15 species), Fabaceae (8 species), Lamiaceae ( 7 species), Apiaceae, and Rosaceae (5 species each). Compositae included plants that are mostly prepared as cooked vegetables. On the other hand, Lamiaceae mainly included the spices and herbs that are consumed, dried, and ground, whereas Rosaceae included the species that are consumed mostly as fresh fruits. Species mentioned only once or twice in the survey were excluded from further analysis.

Sixty-four plant species were reported by at least $6 \%$ of informants (Table 1 ). The following species showed a level of quotation above $80 \%$ of respondents (in descending order of quotation): Origanum syriacum, Rhus coriaria, Eryngium creticum, Cichorium intybus, Micromeria myrtifolia, Allium ampeloprasum, Cirsium vulgare, Gundelia tournefortii, Scandix pecten-veneris, Malva sylvestris, Anchusa strigosa. On the other hand, the species Nasturtium officinale, Rumex acetosa, Thymus vulgaris, and Arum maculatum were used by $60-80 \%$ of informants.

Table 1. Wild plant species used in food and beverage preparation in the study area.

\begin{tabular}{|c|c|c|c|c|c|}
\hline $\begin{array}{l}\text { Botanical } \\
\text { Family }\end{array}$ & $\begin{array}{l}\text { Latin Name (Voucher } \\
\text { Specimen Code) }\end{array}$ & Local Name(s) & Part Used & $\begin{array}{l}\text { Mode of Preparation and } \\
\text { Consumption }\end{array}$ & $\begin{array}{l}\text { Relative } \\
\text { Frequency } \\
\text { of Citation } \\
\left(\mathrm{N}^{1}=50\right)\end{array}$ \\
\hline \multirow{3}{*}{ Amaranthaceae } & $\begin{array}{l}\text { Amaranthus retroflexus } \\
\text { L. }\left(\mathrm{NC}^{2}\right)\end{array}$ & Qttaifeh & Young aerial part & $\begin{array}{l}\text { Steamed with other WFPs (Sleeq); } \\
\text { fried with eggs. }\end{array}$ & 0.16 \\
\hline & Beta vulgaris L. (NC) & Selq barri & Young aerial part & Boiled & 0.1 \\
\hline & $\begin{array}{c}\text { Chenopodium } \\
\text { bonus-henricus L. (NC) }\end{array}$ & Sabanekh barri & Leaves & Boiled & 0.08 \\
\hline Amaryllidaceae & $\begin{array}{l}\text { Allium ampeloprasum } \mathrm{L} \text {. } \\
\quad \text { (Sulaiman } 27)\end{array}$ & Kerrat, Twaimeh & $\begin{array}{l}\text { Young aerial part } \\
\text { and bulb }\end{array}$ & $\begin{array}{l}\text { Fresh; steamed with Sleeq; fried with } \\
\text { eggs, or with minced meat. }\end{array}$ & 0.96 \\
\hline \multirow{3}{*}{ Anacardiaceae } & $\begin{array}{l}\text { Pistacia atlantica Desf. } \\
\text { (NC) }\end{array}$ & Betem & Leaves and fruits & $\begin{array}{l}\text { Spice: leaves are added specifically to } \\
\text { the traditional soup Qishq (it also } \\
\text { serves as a preserver); fruits are added } \\
\text { to Zaatar. }\end{array}$ & 0.36 \\
\hline & $\begin{array}{l}\text { Pistacia terebinthus L. } \\
\quad \text { (Sulaiman } 3)\end{array}$ & Betem & Leaves and fruits & $\begin{array}{l}\text { Spice: leaves are added specifically to } \\
\text { the traditional soup Qishq (it also } \\
\text { serves as a preserver); fruits are added } \\
\text { to Zaatar. }\end{array}$ & 0.36 \\
\hline & $\begin{array}{l}\text { Rhus coriaria L. } \\
\text { (Sulaiman } 14 \text { ) }\end{array}$ & Summaq & Fruits & $\begin{array}{l}\text { Spice added to: salads, Zaatar, boiled } \\
\text { potato, and to the traditional soup } \\
\text { Louf (A. maculatum) }\end{array}$ & 0.98 \\
\hline \multirow{5}{*}{ Apiaceae } & Ammi majus L. & Khelleh & Inflorescence & $\begin{array}{l}\text { Added to yerba mate (to substitute an } \\
\text { amount of yerba mate) [20]. }\end{array}$ & 0.06 \\
\hline & $\begin{array}{l}\text { Apium nodiflorum (L.) } \\
\text { Lag. (NC) }\end{array}$ & Qarrah & Young aerial part & Appetizer & 0.44 \\
\hline & $\begin{array}{l}\text { Eryngium creticum Lam. } \\
\text { (Sulaiman } 11)\end{array}$ & Qers anneh & Young aerial part & Salad; steamed with Sleeq. & 0.98 \\
\hline & $\begin{array}{l}\text { Foeniculum vulgare Mill. } \\
\quad \text { (Sulaiman } 37)\end{array}$ & Shamra & Aerial part & $\begin{array}{c}\text { Spice added to Zaatar and soups; fried } \\
\text { with: eggs / meat/potato or } A \text {. } \\
\text { ampeloprasum. }\end{array}$ & 0.4 \\
\hline & $\begin{array}{l}\text { Scandix pecten-veneris } \mathrm{L} \text {. } \\
\quad \text { (Sulaiman } 20)\end{array}$ & Hert manneh & Young aerial part & Steamed with Sleeq. & 0.84 \\
\hline Araceae & $\begin{array}{l}\text { Arum maculatum L. } \\
\quad \text { (Sulaiman } 31)\end{array}$ & Louf & Young aerial part & $\begin{array}{l}\text { Soup: boiled with } R \text {. acetosa, } R \text {. coriaria, } \\
\text { bulgur (cracked, parboiled groats of } \\
\text { Triticum durum Desf.), and olive oil. }\end{array}$ & 0.66 \\
\hline
\end{tabular}


Table 1. Cont.

\begin{tabular}{|c|c|c|c|c|c|}
\hline $\begin{array}{l}\text { Botanical } \\
\text { Family }\end{array}$ & $\begin{array}{l}\text { Latin Name (Voucher } \\
\text { Specimen Code) }\end{array}$ & Local Name(s) & Part Used & $\begin{array}{l}\text { Mode of Preparation and } \\
\text { Consumption }\end{array}$ & $\begin{array}{l}\text { Relative } \\
\text { Frequency } \\
\text { of Citation } \\
\left(\mathrm{N}^{1}=50\right)\end{array}$ \\
\hline Asparagaceae & $\begin{array}{l}\text { Asparagus acutifolius L. } \\
\text { (Sulaiman 30) }\end{array}$ & Halyoun & Shoots & Fried with eggs; salads; steam frying. & 0.58 \\
\hline Boraginaceae & $\begin{array}{l}\text { Anchusa strigosa Banks } \\
\text { and Sol. (Sulaiman 46) }\end{array}$ & Balasoun & $\begin{array}{l}\text { Young aerial part } \\
\text { and underground } \\
\text { stem }\end{array}$ & $\begin{array}{l}\text { Fried; steamed with olive oil, and } \\
\text { garlic or onion. }\end{array}$ & 0.82 \\
\hline \multirow{3}{*}{ Brassicaceae } & $\begin{array}{l}\text { Lepidium ruderale } \mathrm{L} . \\
\text { (NC) }\end{array}$ & Reshad barri & Young aerial part & Appetizer & 0.48 \\
\hline & $\begin{array}{l}\text { Nasturtium officinale } \\
\text { R.Br. (NC) }\end{array}$ & Jarjeer & Young aerial part & Appetizer & 0.78 \\
\hline & $\begin{array}{l}\text { Sinapis arvensis } \mathrm{L} . \\
\text { (Sulaiman } 18 \text { ) }\end{array}$ & Fejjaileh & Young aerial part & $\begin{array}{l}\text { Steamed with Sleeq; boiled, and then } \\
\text { olive oil and lemon are added; fried } \\
\text { with eggs. }\end{array}$ & 0.22 \\
\hline Campanulaceae & $\begin{array}{l}\text { Michauxia campanuloides } \\
\text { L'Hér. (NC) }\end{array}$ & Qarf awn & $\begin{array}{l}\text { Young aerial part, } \\
\text { root }\end{array}$ & $\begin{array}{l}\text { Steamed with Sleeq; steamed with } \\
\text { onion and carrot. }\end{array}$ & 0.16 \\
\hline Caryophyllaceae & $\begin{array}{l}\text { Silene dioica (L.) Clairv. } \\
\quad \text { (Sulaiman 32) }\end{array}$ & Lbas alqetah & Young aerial part & Steamed with Sleeq. & 0.2 \\
\hline \multirow{14}{*}{ Compositae } & $\begin{array}{l}\text { Centaurea calcitrapa L. } \\
\quad(\text { Sulaiman } 4)\end{array}$ & Qellaibeh, Dardar & Young aerial part & Steamed with Sleeq. & 0.18 \\
\hline & $\begin{array}{l}\text { Cichorium intybus L. } \\
\quad \text { (Sulaiman } 43 \text { ) }\end{array}$ & Hendbeh & Young aerial part & $\begin{array}{l}\text { Shabshuleh: boiled, then olive oil and } \\
\text { lemon juice and garlic are added; } \\
\text { steamed with Sleeq. }\end{array}$ & 0.98 \\
\hline & $\begin{array}{l}\text { Cirsium vulgare (Savi) } \\
\text { Ten. (Sulaiman } 8 \text { ) }\end{array}$ & Qessitah & $\begin{array}{l}\text { Leaves midrib and } \\
\text { underground stem }\end{array}$ & $\begin{array}{l}\text { Steamed with Sleeq; steamed } \\
\text { with chickpea. }\end{array}$ & 0.88 \\
\hline & $\begin{array}{l}\text { Crepis sancta (L.) Bornm. } \\
\text { (NC) }\end{array}$ & $\begin{array}{c}\text { Del 'a alhelou, Qers } \\
\text { alhelou }\end{array}$ & Young aerial part & Steamed with Sleeq. & 0.08 \\
\hline & $\begin{array}{l}\text { Crepis vesicaria } \mathrm{L} . \\
\text { (Sulaiman } 45)\end{array}$ & Harbsees & Young aerial part & Steamed with Sleeq. & 0.36 \\
\hline & $\begin{array}{l}\text { Cynara syriaca Boiss. } \\
\text { (NC) }\end{array}$ & $\begin{array}{l}\text { Ardi shouki barri, } \\
\text { Kharshouf }\end{array}$ & Inflorescence & Steamed with minced meat. & 0.1 \\
\hline & $\begin{array}{l}\text { Gundelia tournefortii L. } \\
\quad \text { (Sulaiman 19) }\end{array}$ & Salbeen & $\begin{array}{l}\text { Leaves midrib and } \\
\text { underground stem }\end{array}$ & $\begin{array}{l}\text { Steamed with chickpea and olive oil; } \\
\text { steamed with onion and olive oil; } \\
\text { steamed with minced meat; cooked } \\
\text { with rice. }\end{array}$ & 0.86 \\
\hline & $\begin{array}{l}\text { Helminthotheca echioides } \\
\text { (L.) Holub } \\
\text { (Sulaiman 44) }\end{array}$ & Khishan & Young aerial part & Steamed with Sleeq. & 0.28 \\
\hline & $\begin{array}{l}\text { Leontodon hispidus L. } \\
\quad \text { (Sulaiman 16) }\end{array}$ & Sliq aloud & Young aerial part & Steamed with Sleeq. & 0.28 \\
\hline & $\begin{array}{l}\text { Matricaria chamomilla } \\
\text { L. (NC) }\end{array}$ & Babounej & Flowers & Tea; added to yerba mate. & 0.08 \\
\hline & $\begin{array}{l}\text { Notobasis syriaca (L.) } \\
\text { Cass. (NC) }\end{array}$ & $\begin{array}{l}\text { Shok aljamal, } \\
\text { Kherfesh, Qailouh, } \\
\text { Shouk alqed }\end{array}$ & Leaves midrib & $\begin{array}{l}\text { Steamed with onion and olive oil; } \\
\text { boiled then steamed with } \\
\text { minced meat. }\end{array}$ & 0.12 \\
\hline & $\begin{array}{l}\text { Silybum marianum (L.) } \\
\text { Gaertn. (Sulaiman } 48 \text { ) }\end{array}$ & Labboun & $\begin{array}{l}\text { Leaves midrib and } \\
\text { underground stem }\end{array}$ & $\begin{array}{l}\text { Steamed with onion and olive oil; } \\
\text { steamed with Sleeq; steamed with } \\
\text { chickpea and olive oil, steamed with } \\
\text { minced meat and then mixed } \\
\text { with yogurt. }\end{array}$ & 0.34 \\
\hline & $\begin{array}{l}\text { Sonchus oleraceus (L.) } \\
\text { L. (NC) }\end{array}$ & $\begin{array}{l}\text { Khesaiseh, Asat } \\
\text { alraa'I, Elk alghazal }\end{array}$ & Young aerial part & Steamed with Sleeq. & 0.18 \\
\hline & $\begin{array}{l}\text { Tragopogon pratensis } \mathrm{L} . \\
\quad \text { (Sulaiman } 9 \text { ) }\end{array}$ & $\begin{array}{l}\text { Daqen alshaikh, } \\
\text { Daqen alkhouri }\end{array}$ & Young aerial part & Steamed with Sleeq. & 0.1 \\
\hline
\end{tabular}


Table 1. Cont.

\begin{tabular}{|c|c|c|c|c|c|}
\hline $\begin{array}{l}\text { Botanical } \\
\text { Family }\end{array}$ & $\begin{array}{l}\text { Latin Name (Voucher } \\
\text { Specimen Code) }\end{array}$ & Local Name(s) & Part Used & $\begin{array}{l}\text { Mode of Preparation and } \\
\text { Consumption }\end{array}$ & $\begin{array}{l}\text { Relative } \\
\text { Frequency } \\
\text { of Citation } \\
\left(\mathbf{N}^{1}=50\right)\end{array}$ \\
\hline Cucurbitaceae & $\begin{array}{l}\text { Bryonia cretica L. } \\
\text { (Sulaiman } 36 \text { ) }\end{array}$ & Atairisheh & Leaves & Fried with eggs. & 0.36 \\
\hline Geraniaceae & $\begin{array}{l}\text { Erodium acaule (L.) Bech. } \\
\text { and Thell. } \\
\text { (Sulaiman } 10)\end{array}$ & Mssaikeh & Young aerial part & Steamed with Sleeq. & 0.48 \\
\hline \multirow{7}{*}{ Lamiaceae } & Mentha piperita L. (NC) & Nana 'a barri & Leaves and shoots & Appetizer; salads; tea. & 0.08 \\
\hline & $\begin{array}{l}\text { Micromeria myrtifolia } \\
\text { Boiss. and Hohen. } \\
\text { (Sulaiman 29) }\end{array}$ & Zoufa & Aerial part & Tea; added to yerba mate. & 0.98 \\
\hline & $\begin{array}{l}\text { Origanum syriacum L. } \\
\text { (Sulaiman } 24 \text { ) }\end{array}$ & $Z a u b a^{\prime}$ & Leaves & $\begin{array}{l}\text { Main ingredient of Zaatar (dried and } \\
\text { grinded and then R. coriaria and } \\
\text { sesame are added); condiment with } \\
\text { salad and strained yogurt; added to } \\
\text { yerba mate. }\end{array}$ & 1 \\
\hline & Salvia officinalis L. (NC) & $\begin{array}{l}\text { Quaisineh, Qasa'een, } \\
\text { Mariamiah }\end{array}$ & Leaves & Added to yerba mate. & 0.06 \\
\hline & $\begin{array}{l}\text { Teucrium procerum Boiss. } \\
\text { and Blanche. }(\mathrm{NC})\end{array}$ & Qentariah & Aerial part & Added to yerba mate. & 0.12 \\
\hline & $\begin{array}{l}\text { Thymus vulgaris } \mathrm{L} . \\
\text { (Sulaiman 25) }\end{array}$ & Za'atar barri & Leaves & $\begin{array}{l}\text { Fresh as a condiment for salads; dried } \\
\text { and grinded as spices for the } \\
\text { traditional cheese Shanklish; added } \\
\text { to Zaatar. }\end{array}$ & 0.72 \\
\hline & Ziziphora sp. (NC) & Qernaieh & Young aerial part & $\begin{array}{c}\text { Steamed with Sleeq; added to } \\
\text { yerba mate. }\end{array}$ & 0.1 \\
\hline Lauraceae & $\begin{array}{l}\text { Laurus nobilis L. } \\
\text { (Sulaiman 33) }\end{array}$ & Ghar & Leaves & Flavoring of meat. & 0.2 \\
\hline \multirow{5}{*}{ Fabaceae } & $\begin{array}{l}\text { Cercis siliquastrum } \mathrm{L} . \\
\quad \text { (Sulaiman } 40)\end{array}$ & Shajreeq & Flowers & Snack & 0.12 \\
\hline & $\begin{array}{c}\text { Melilotus officinalis (L.) } \\
\text { Pall. (Sulaiman 47) }\end{array}$ & Handkouq & Young aerial part & Steamed with Sleeq. & 0.12 \\
\hline & Lathyrus sativus L. (NC) & Jelbaneh & Fruits & Snack & 0.06 \\
\hline & $\begin{array}{l}\text { Trifolium pratense } \mathrm{L} . \\
\quad \text { (Sulaiman } 35 \text { ) }\end{array}$ & Neffleh & Flowers & Added to yerba mate. & 0.06 \\
\hline & $\begin{array}{c}\text { Trigonella } \\
\text { foenum-graecum } \mathrm{L} . \\
\text { (Sulaiman } 41 \text { ) }\end{array}$ & Helbeh & Fruits & Added to yerba mate. & 0.28 \\
\hline \multirow{2}{*}{ Malvaceae } & $\begin{array}{l}\text { Corchorus olitorius L. } \\
\text { (NC) }\end{array}$ & Mlokhiah & Leaves & $\begin{array}{l}\text { Soup: with meat, oil, and lemon } \\
\text { added on taste. }\end{array}$ & 0.08 \\
\hline & $\begin{array}{l}\text { Malva sylvestris L. } \\
\text { (Sulaiman 23) }\end{array}$ & Khebbaizeh & Young aerial part & $\begin{array}{l}\text { Marshusheh: steamed with onion, olive } \\
\text { oil and a bit of bulgur). }\end{array}$ & 0.84 \\
\hline Myrtaceae & $\begin{array}{l}\text { Myrtus communis L. } \\
\quad \text { (Sulaiman } 7)\end{array}$ & Hinblas & Fruits & Snack & 0.14 \\
\hline Plantaginaceae & $\begin{array}{l}\text { Plantago lanceolata } \mathrm{L} . \\
\text { (NC) }\end{array}$ & Lsan alhamal & Young aerial part & Steamed with Sleeq. & 0.1 \\
\hline Polygonaceae & $\begin{array}{l}\text { Rumex acetosa } \mathrm{L} . \\
\text { (Sulaiman } 38 \text { ) }\end{array}$ & Hmmaidah & Young aerial part & $\begin{array}{l}\text { Steamed with Sleeq; boiled as a soup } \\
\text { with A. maculatum; rice stuffing; salad. }\end{array}$ & 0.74 \\
\hline Portulacaceae & $\begin{array}{l}\text { Portulaca oleracea } \mathrm{L} . \\
\text { (NC) }\end{array}$ & Beqaileh barriah & Young aerial part & Salad & 0.28 \\
\hline
\end{tabular}


Table 1. Cont.

\begin{tabular}{|c|c|c|c|c|c|}
\hline $\begin{array}{l}\text { Botanical } \\
\text { Family }\end{array}$ & $\begin{array}{l}\text { Latin Name (Voucher } \\
\text { Specimen Code) }\end{array}$ & Local Name(s) & Part Used & $\begin{array}{c}\text { Mode of Preparation and } \\
\text { Consumption }\end{array}$ & $\begin{array}{c}\text { Relative } \\
\text { Frequency } \\
\text { of Citation } \\
\left(\mathrm{N}^{1}=50\right)\end{array}$ \\
\hline \multirow{2}{*}{ Primulaceae } & $\begin{array}{l}\text { Cyclamen libanoticum } \\
\text { Hildebr. (NC) }\end{array}$ & Doghnain & Leaves & Rice stuffing & 0.4 \\
\hline & $\begin{array}{l}\text { Cyclamen persicum Mill. } \\
\text { (Sulaiman 15) }\end{array}$ & Doghnain & Leaves & Rice stuffing & 0.4 \\
\hline \multirow{2}{*}{ Ranunculaceae } & $\begin{array}{l}\text { Anemone coronaria } \mathrm{L} . \\
\quad(\text { Sulaiman } 1)\end{array}$ & Shaqaeq alnoa'man & Young aerial part & Steamed with Sleeq. & 0.4 \\
\hline & $\begin{array}{l}\text { Ficaria verna Huds. } \\
\quad \text { (Sulaiman } 34)\end{array}$ & Mghayriqah & Young aerial part & Steamed with Sleeq. & 0.06 \\
\hline \multirow{4}{*}{ Rosaceae } & $\begin{array}{c}\text { Crataegus azarolus L. } \\
\text { (NC) }\end{array}$ & Za'arour asfar & Fruits, Flowers & Snack & 0.38 \\
\hline & $\begin{array}{l}\text { Crataegus monogyna } \\
\text { Jacq. (Sulaiman 5) }\end{array}$ & Za'arour ahmar & Fruits, Flowers & Snack & 0.38 \\
\hline & $\begin{array}{l}\text { Pyrus syriaca Boiss. } \\
\text { (Sulaiman 13) }\end{array}$ & Mrab barri & Fruits & Fruit & 0.08 \\
\hline & $\begin{array}{l}\text { Rubus sanctus Schreb. } \\
\text { (Sulaiman 6) }\end{array}$ & Dees & Fruits & Snack & 0.08 \\
\hline Urticaceae & Urtica dioica L. (NC) & Qerras & Young aerial part & Steamed with Sleeq. & 0.12 \\
\hline
\end{tabular}

${ }^{1}$ : $\mathrm{N}=$ number of informants; ${ }^{2}: \mathrm{NC}=$ not collected.

\subsection{Most Common Wild Plant-Based Dishes}

\subsubsection{Sleeq}

Sleeq is the most popular wild plant-based dish in the study area. It is prepared from gathered wild leafy vegetables. The name Sleeq is probably derived from the word Saleeq, which in the Arabic language means boiled food; however, the dish is mainly prepared by steaming, rather than boiling. The same dish was also called Mhabbleh by some informants, which locally refers to steamed food. There is no limitation to what kind of or how many wild vegetables can be included in the preparation. The most common species used in the preparation of Sleeq are Scandix pecten-veneris, Cirsium vulgare, Allium ampeloprasum, Erodium acaule, Cichorium intybus, Anchusa strigosa, Gundelia tournefortii, Silybum marianum, Rumex acetosa, Anemone coronaria, Malva sylvestris, and Urtica dioica. Practically every wild leafy vegetable that is able to be gathered by the collectors can be included in the dish, since it is sometimes difficult to gather a sufficient amount from one species only. The young shoots are the main part used in the Sleeq. The dish is mostly prepared in a local traditional clay pan called Meqli (see the video abstract), where chopped onion is fried in olive oil, then cut wild leafy vegetables are added. Some informants add a small amount of chickpea and/or softly ground bulgur if available. Several informants reported that it is possible to use Sleeq as a topping on the dough to be prepared as pizza, with the same mentioned receipt excluding chickpea and bulgur. Sleeq is a seasonal food connected with the availability of wild leafy vegetables usually collected from January to April.

\subsubsection{Zaatar}

Traditional food in many regions in Syria. It is a sour spicy dish consumed by mixing with olive oil, usually in breakfast and dinner meals, as well as in Zaatar bread/pizza. The dried and ground leaves of Origanum syriacum, the main ingredient of Zaatar, are mixed with dried ground fruits of Rhus coriaria, and roasted seeds of Sesamum spp. in the following proportion: 1.0 of Origanum syriacum, 0.75 of Rhus coriaria, 1.0 of Sesamum spp. Dried fruits of Pistacia terebinthus/Pistacia atlantica and seeds of Foeniculum vulgare may be sprinkled as spices. Zaatar is usually stored dried in jars or plastic bags, and consumed over the whole year. 


\subsubsection{Louf Soup}

Louf is a traditional soup consumed only in some parts of the Syrian coastal mountains, especially by the Alawite and Ismaili cultural-religious groups. The soup has a sourastringent taste with a thick texture. Arum maculatum is the main ingredient in Louf soup; its dark-green leaves are loosely cut and steamed for around half an hour. Afterwards, olive oil and bulgur are added, then the water of boiled Rhus coriaria is added after disposing of Rhus coriaria. Arum maculatum contains a high amount of calcium oxalate, which is a toxic compound [56]; however, as local people are aware of this toxicity, it is thus prepared by boiling for more than an hour to detoxify it. The dish is characterized as a winter soup, as Arum maculatum is usually available from December to April. Some informants reported that they store it in glass jars in the refrigerator and consume it throughout the year.

\subsubsection{Shabshuleh}

The young aerial part of Cichorium intybus is boiled for around half an hour, then olive oil, crushed garlic, and a little bit of lemon juice are added (Figure 2). It is typically consumed between January and April before Cichorium intybus starts flowering.
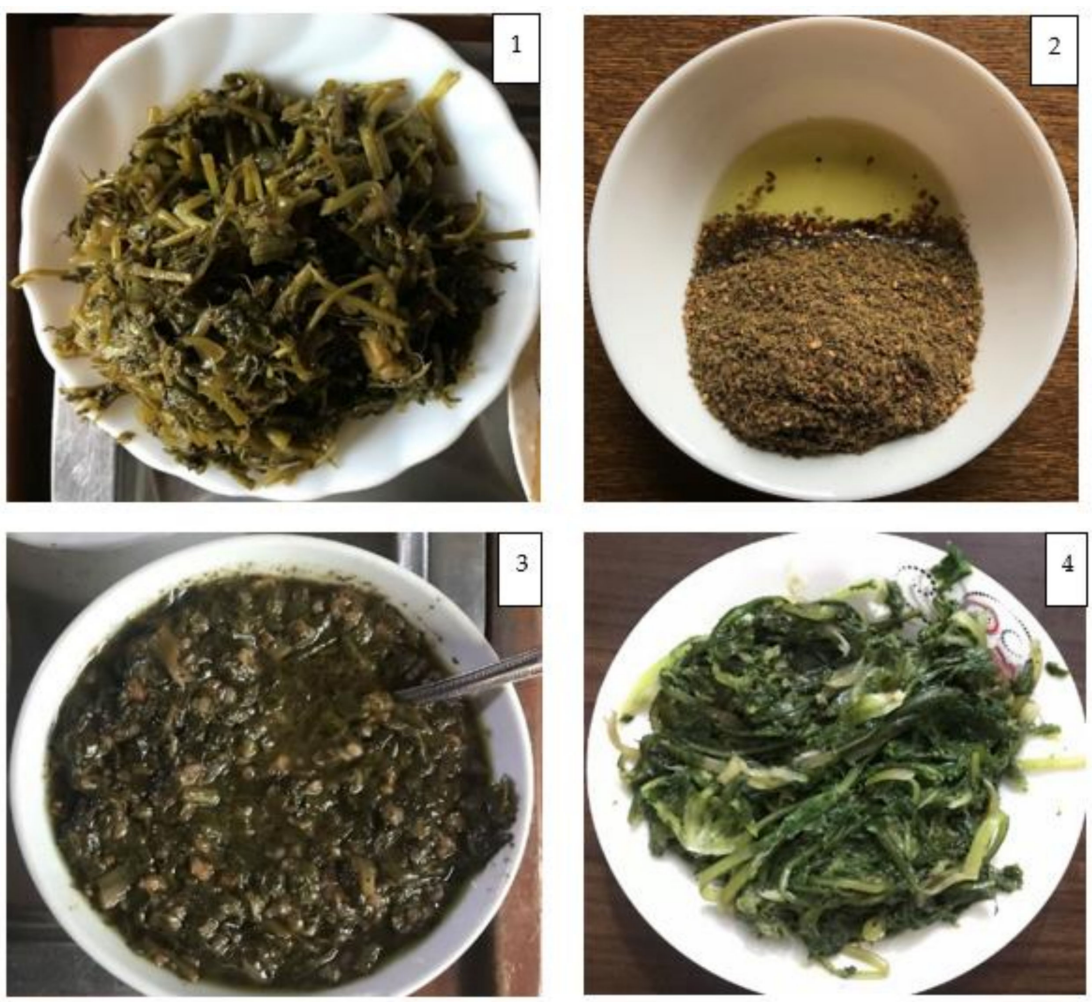

Figure 2. The most popular wild plant-based dishes. (1): Sleeq dish; (2): Zaatar dish with olive oil; (3): Louf soup; (4): Shabshuleh dish.

\section{Discussion}

\subsection{Emergency Behavioral Reaction: Reliance Increase on Wild Food Plants during the Conflict}

The reported increase of wild plant use during the conflict compared to the pre-conflict time clearly shows the effect of the conflict-associated economic crisis on the informants' behavior toward food-securing. This finding is strongly supported by the respondents' statements that highlighted economic reasons as the main motive behind such an increase. Wild plant foraging shifted from a complementary and entertainment activity for many informants a decade ago, to an important and necessary action in recent years. Such an emergency reaction went beyond being individual in other countries; in the winter of 1944-1945, the Dutch government provided information on wild plants and other famine food sources in the so-called "wartime cookbooks" [11]. Similarly, Redžić [3] broadcasted 
information over the radio to assist local people to find edible plants as a quick reaction to food scarcity during the siege of Sarajevo in the Balkan war. Several other studies around the globe concluded that wild plant use and their related traditional knowledge served as a coping mechanism in response to food shortages [57-59]. Hence, traditional ecological knowledge (TEK) has to be conserved by societies, apart from its cultural importance, due to its ability to save the lives of millions of people in times of future crisis. Many obstacles stand in the way of TEK preservation, such as the invasion of fast food and prestige-related perception of local food. However, several strategies could be followed to preserve TEK, such as marketing the local food based on traditional knowledge, documenting TEK, raising awareness of its importance, and teaching the skill of recognizing and collecting wild plants to school students.

Changes in diet in the study area have mainly been represented by the decrease in buying market food products and increase in the use of WFPs, particularly leafy vegetables. Most commodities' prices in Syria have increased tens of times since the beginning of the conflict. However, a few products are still affordable by the majority due to the government supporting these products. Bread, which is the main part of every meal, is one of these affordable commodities at 0.06 US Dollars per $1 \mathrm{~kg}(1 \mathrm{USD}=3500$ Syrian Pounds according to the market exchange rate of late October 2021). Olive oil is produced by the majority of people in the study area where olive orchards dominate the landscape. Vegetable prices in the market vary between 0.3 to 1.4 USD for $1 \mathrm{~kg}$, and prices for $1 \mathrm{~kg}$ of meat range between 2.9 and 5.7 USD. Those prices are considered relatively high and commonly unaffordable compared to the average monthly salary of 149,000 SP $\approx 43$ USD [60]. Hence, we find that bread, olive oil, and gathered WFPs form the key ingredients for the most affordable food (e.g., Sleeq). Wild vegetables are also sold in the local markets at a lower price than other cultivated vegetables; for instance, the price of $1 \mathrm{~kg}$ of wild leafy vegetables (Sleeq) varies between 0,28 and 0,42 USD. We observed that several informants attempted to cultivate some wild species (e.g., Origanum syriacum, Thymus vulgaris) in their home gardens. Some people living in the cities and town centres (where access to wild plants is limited) depended on their relatives and friends in rural areas to gather WFPs for them.

\subsection{Comparison of the Reported Wild Plant Diversity with Other Regions and Cultural Importance of Some Reported Species}

The total number of 75 documented WFPs in the study area represents relatively high diversity compared to the Eastern Mediterranean region. It demonstrates a richness in the wild-related food culture. Kawas et al. [18] documented eight wild edible species out of 145 wild plants found in Hama Steppe in central Syria. On the other hand, 42 wild plant species are used in the Assyrian cuisine in the Eastern Syrian-Turkish borderland [19]. The majority of the reported plants in our study were not mentioned in either study of Kawas et al. [18] or Abdalla [19]; this is possibly due to the difference in ecosystems and vegetation types. Lower diversity of WFPs was found in Lebanon with 32 recorded species [23,24]. On the other hand, high diversity was noted in Adana in Turkey (76 documented species) and Cyprus with 78 recorded species $[25,28]$. On the other side of the Syrian borders, Pieroni et al. [43] documented 34 taxa used as WFPs in the Kurdistan region in Northern Iraq. The high diversity in species used in our study area could be attributed to the emergency situation, which pushed local people to use every edible plant available in the surrounding environment. Figure 3 shows the overlap in the used WFPs between our study (64 species in Table 1), and studies selected from the closest countries to our study area represented by Lebanon [23], Cyprus [25], and Turkey [28]. The overlap demonstrates the Mediterranean influence on the wild plant-based diet in our study area, where $41 \%$ of our species (26 out of 64 ) was used in food preparation in the other compared studies. More than one-fourth (17) of our reported species were used in Cyprus, and some species were similarly prepared; this is possibly due to the geographical closeness to our study area. In addition to the overlap in used species between the selected study areas, more similarities were found in genera; this is due to the presence of different 
species that belong to the same genus. The use of Gundelia tournefortii is documented in all compared studies; this is possibly due to its pleasant taste, as our study informants reported that it is one of the most preferred WFPs. It is usually steamed in olive oil with minced meat or chickpeas. Several plant species were found to be unique to the study area, such as Arum maculatum, which is a very popular and traditional soup (Louf) in some parts of the study area. All the species that comprise the most common wild plant-based dishes are culturally important and often frequently used. Despite that some of these species are less available nowadays in the wild, they still remain highly preferred, and this is possibly due to their pleasant taste or their importance in the local culture as a main part of the traditional diet. Based on the results and our observation, the sour-astringent taste was found to be preferred by many informants, especially from Alawites and Ismailis, which was demonstrated by the high use of some wild species, such as Arum maculatum and Rhus coriaria, which were described by some informants as "the sour of Phoenicians".

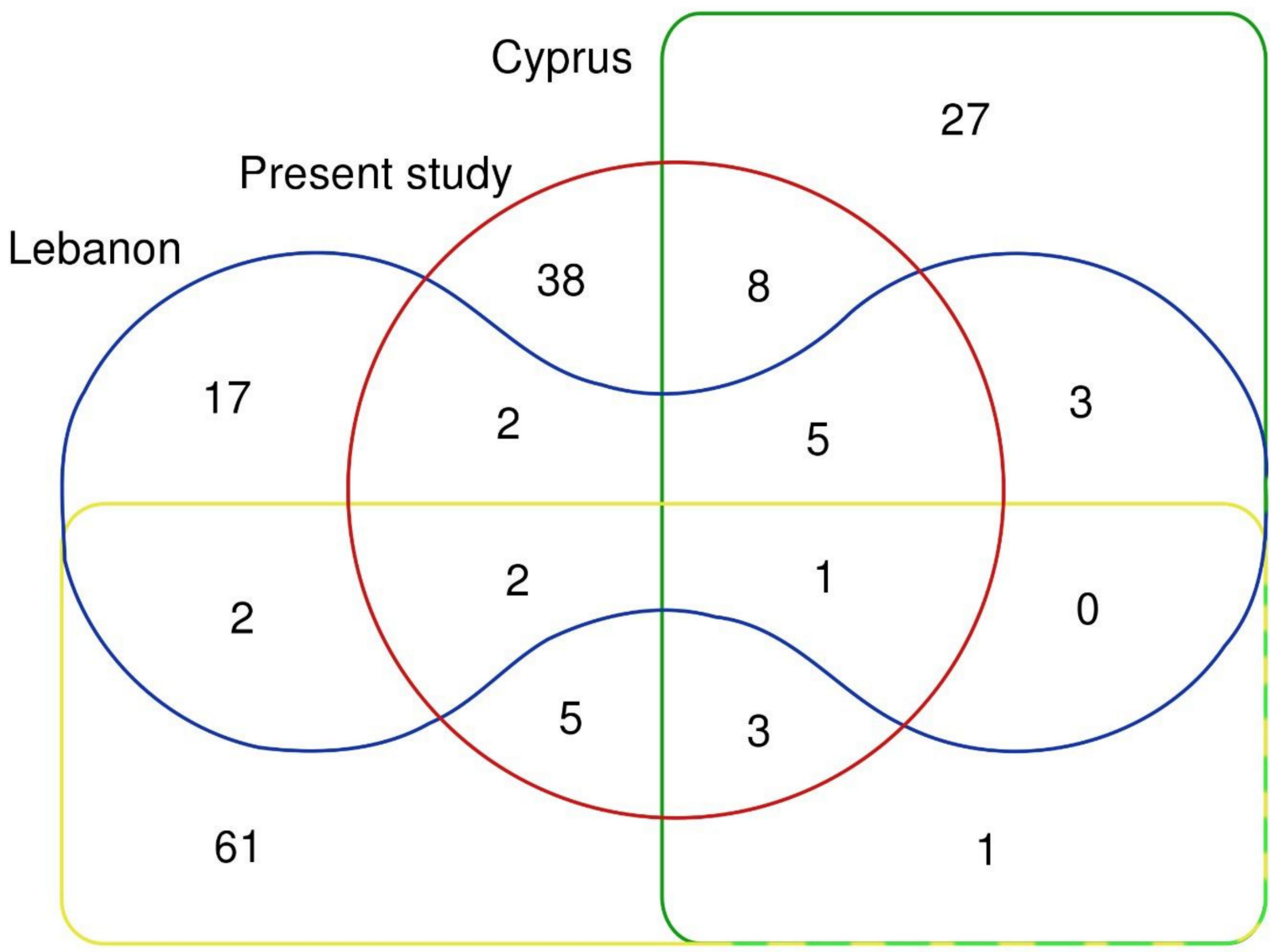

\section{Turkey}

Figure 3. Overlap of used wild food plants between our study and selected studies from some East Mediterranean countries (numbers refer to the overlapping species).

\subsection{Nutritive Value of the Most Quested Species}

There is a deficiency of data on nutritional status in Syria, especially considering that the situation is getting worse every year with the continued conflict, economic sanctions, and conflict-related chaos and corruption. However, a report from WFP [61] showed a high level $(12.7 \%)$ of chronic malnutrition amongst children under the age of five. Anaemia is widespread amongst both children under the age of five and women with a prevalence of $25.9 \%$ and $24.5 \%$, respectively. Here, iron-rich WFPs, such as Scandix pecten-veneris, Gundelia tournefortii, and Nasturtium officinale, as well as other dark-green leafy wild vegetables, such as Arum maculatum) could play a significant role in preventing anaemia (Table 2). 
In times of COVID-19 and immunity-related diseases, species rich in zinc content, such as Scandix pecten-veneris and Allium ampeloprasum, could significantly help local people due to the direct effect of $\mathrm{Zn}$ on the overall activity of the immunity system [62]. Some of the reported species, especially those which are quoted by the majority, have shown a general richness in nutritional value and health benefits (Table 2). Species such as Origanum syriacum and Thymus vulgaris demonstrated a richness in antioxidants. The protein content was particularly high in some species, such as Rumex acetosa. Hence, for instance, the wild plant-based meal of Sleeq which contains wild leafy vegetables (rich in minerals and vitamins), olive oil (a significant source of unsaturated fatty acids), bulgur (protein-rich cereal), and bread (a main source of carbohydrates) serves as a good source of essential nutrients for the human body.

Table 2. Main nutritional benefits of WFPs, which are among the most reported in the current study.

\begin{tabular}{|c|c|c|}
\hline Species Name & Part Used & Main Nutritional Benefits \\
\hline Origanum syriacum & Leaves & Antioxidant [52]. \\
\hline Rhus coriaria & Fruits & $\begin{array}{l}\text { Good source of phenolics, anthocyanins, organic acids (e.g., malic } \\
\text { acid, citric acid and ascorbic acid) and carbohydrates [44]. }\end{array}$ \\
\hline Eryngium creticum & Young aerial part & Rich in antioxidant [49]. \\
\hline Cichorium intybus & Young aerial part & $\begin{array}{l}\text { Rich in } \mathrm{K}, \mathrm{P} \text {, and vitamin } \mathrm{C} \text {. It has anti-inflammatory and } \\
\text { anti-diabetic activity [45]. }\end{array}$ \\
\hline Allium ampeloprasum & Young aerial part and bulb & Good source of fiber and zinc [48]. \\
\hline Gundelia tournefortii & Leaves midrib and underground stem & $\begin{array}{l}\text { Good source for minerals } \mathrm{K}, \mathrm{Ca}, \mathrm{P}, \mathrm{Na}, \mathrm{Fe}, \mathrm{Mg} \text {, and } \mathrm{Zn} \text {; as well as } \\
\text { in vitamin } \mathrm{E}[50] .\end{array}$ \\
\hline Scandix pecten-veneris & Young aerial part & Highly rich in Fe; a significant source of $\mathrm{Zn}$ [53]. \\
\hline Malva sylvestris & Young aerial part & Rich in $\mathrm{Ca}, \mathrm{Mg}$, and $\mathrm{K}$ [51]. \\
\hline Nasturtium officinale & Young aerial part & A good source of $\mathrm{K}$ and Fe [53]. \\
\hline Rumex acetosa & Young aerial part & Rich in proteins $[47,54]$. \\
\hline Thymus vulgaris & Leaves & $\begin{array}{l}\text { Has antioxidative, anti-inflammatory, antibacterial and antifungal } \\
\text { activity [46]. }\end{array}$ \\
\hline
\end{tabular}

\section{Conclusions}

The field study that we conducted among the local people in the coastal region of Syria showed a remarkable level of reliance on WFPs as a source of human nutrition. The study demonstrated the increased use of WFPs during the conflict compared to the preconflict time. Our results strengthened the findings of previous studies that ethnobotanical knowledge functions as a coping method for food shortage. We documented 75 wild plant species used in food and beverage preparation with a relatively high diversity comparing to other studies from the Eastern Mediterranean. The most common wild food-based dishes and their preparation mode were documented. Some species, such as O. syriacum, G. tournefortii, and R. acetosa demonstrated a richness in nutrient content. More research will help determine the exact nutritional role that these WFPs play in supplementing local diets during the conflict. Understanding the perceptions of local people towards WFPs could help in planning successful promotion of some nutritive species. Furthermore, future studies should consider the sustainability of WFP use and how these plants could be protected during crises.

Author Contributions: Study design: N.S. and Z.P.; conceptualization: N.S., A.P., R.S. and Z.P.; data curation: N.S., A.P., R.S. and Z.P.; formal analysis: N.S.; funding acquisition: Z.P.; investigation: N.S.; methodology: N.S. and Z.P.; project administration: N.S. and Z.P.; resources: Z.P.; software: N.S.; supervision: Z.P.; validation: A.P., R.S. and Z.P.; visualization: N.S.; writing一original draft: N.S.; 
writing-review and editing: A.P., R.S. and Z.P. All authors have read and agreed to the published version of the manuscript.

Funding: The study was funded by the Internal Grant Agency of the Faculty of Tropical AgriSciences, Czech University of Life Sciences Prague (IGA FTZ, Project No. 20213113).

Institutional Review Board Statement: Not applicable.

Informed Consent Statement: The Code of Ethics of the International Society of Ethnobiology (ISE, 2008) was rigorously followed. Additionally, verbal consent was always obtained before each interview; and participants were fully informed about the objectives and purpose of the proposed research.

Data Availability Statement: The data presented in this study are available on a reasonable request from the corresponding author.

Acknowledgments: We are thankful to local people who shared with us their knowledge and time. We would like to thank, from the Czech University of Life Sciences Prague, Jana Hummelová for the administrative support and Miroslava Bavorová for the provided consultation on the questionnaire. We also thank Cory Whitney from the University of Bonn for his critical and beneficial review of the questionnaire and study proposal, Magda Mofleh and Shadi Faskha from the General Commission for Scientific Agricultural Research in Syria for the administrative support during the fieldwork, and Nada Sinnu from the herbarium of the American University of Beirut. We also thank the five anonymous reviewers for their detailed and very beneficial reviews.

Conflicts of Interest: All authors declare that they have no conflict of interest.

\section{References}

1. Maslow, A.H. A Dynamic Theory of Human Motivation. In Understanding Human Motivation; Stacey, C.L., DeMartino, M., Eds.; Howard Allen Publishers: Cleveland, OH, USA, 1958; pp. 26-47. [CrossRef]

2. The State of Food Security and Nutrition in the World 2020. 2020. FAO Web Site. Available online: http://www.fao.org/ documents/card/en/c/ca9692en (accessed on 28 November 2021).

3. Redžić, S.; Ferrier, J. The Use of Wild Plants for Human Nutrition During a War: Eastern Bosnia (Western Balkans). In Ethnobotany and Biocultural Diversities in the Balkans; Pieroni, A., Quave, C.L., Eds.; Springer: New York, NY, USA, 2014; pp. 149-182. [CrossRef]

4. Prance, G. Ethnobotany, the science of survival: A declaration from Kaua'i. Econ. Bot. 2007, 61, 1-2. [CrossRef]

5. Sõukand, R. Perceived reasons for changes in the use of wild food plants in Saaremaa, Estonia. Appetite 2016, 107, $231-241$. [CrossRef]

6. Quave, C.L.; Pieroni, A. Fermented foods for food security and food sovereignty in the Balkans: A case study of the Gorani people of Northeastern Albania. J. Ethnobiol. 2014, 34, 28-43. [CrossRef]

7. Ocho, D.L.; Struik, P.C.; Price, L.L.; Kelbessa, E.; Kolo, K. Assessing the levels of food shortage using the traffic light metaphor by analyzing the gathering and consumption of wild food plants, crop parts and crop residues in Konso, Ethiopia. J. Ethnobiol. Ethnomed. 2012, 8, 1-17. [CrossRef]

8. Cruz-Garcia, G.S.; Price, L.L. Gathering of wild food plants in anthropogenic environments across the seasons: Implications for poor and vulnerable farm households. Ecol. Food Nutr. 2014, 53, 363-389. [CrossRef]

9. Redžić, S. Use of wild and semi-wild edible plants in nutrition and survival of people in 1430 days of siege of Sarajevo during the war in Bosnia and Herzegovina (1992-1995). Coll. Antropol. 2010, 34, 551-570.

10. Redžić, S.; Barudanovic, S.; Pilipovic, S. Wild mushrooms and lichens used as human food for survival in war conditions; Podrinje-Zepa Region (Bosnia and Herzegovina, W. Balkan). Human Ecol. Rev. 2010, 17, 175-187.

11. Vorstenbosch, T.; de Zwarte, I.; Duistermaat, L.; van Andel, T. Famine food of vegetal origin consumed in the Netherlands during World War II. J. Ethnobiol. Ethnomedicine 2017, 13, 63. [CrossRef]

12. Hanson, T.; Brooks, T.M.; Da Fonseca, G.A.B.; Hoffmann, M.; Lamoreux, J.F.; MacHlis, G.; Mittermeier, C.G.; Mittermeier, R.A.; Pilgrim, J.D. Warfare in biodiversity hotspots. Conserv. Biol. 2009, 23, 578-587. [CrossRef]

13. Country Brief. 2019. World Food Programme Web Site. Available online: https://docs.wfp.org/api/documents/WFP-00001103 24/download/ (accessed on 28 November 2019).

14. WFP Syria: Situation Report \#5. 2021. World Food Programme Web Site. Available online: https://api.godocs.wfp.org/api/ documents / 63eb0734103a49d8a54d7a1ef1171f72/download/?_ga=2.193550317.1391806201.1626620016-1599089406.162662001 6 (accessed on 28 November 2021).

15. Monitoring food Security in Countries with Conflict Situations (Issue No.5). 2019. FAO Web Site. Available online: http: / / www.fao.org/3/ca3113en/CA3113EN.pdf (accessed on 28 November 2021).

16. Global Nutrition Report. Syrian Arab Republic. 2020. Global Nutrition Report Web Site. Available online: https:/ /globalnutritionreport. $\mathrm{org} /$ resources/nutrition-profiles/asia/western-asia/syrian-arab-republic/ (accessed on 28 November 2021). 
17. Nebel, S.; Pieroni, A.; Heinrich, M. Ta chòrta: Wild edible greens used in the Graecanic area in Calabria, Southern Italy. Appetite 2006, 47, 333-342. [CrossRef]

18. Kawas, M.; Abass, G.; Alkhaleel, S. Primary Study of Plants About Importance of the Wild Plants for Local People at Debah Site Hama Steppe Syria. Al-Baath Univ. J. 2014, 36, 223-243. (In Arabic)

19. Abdalla, M. Wild growing plants in the cuisine of modern Assyrians in the Eastern Syrian-Turkish borderland. J. Assyrian Acad. Stud. 2004, 18, 50-58.

20. Sulaiman, N.; Pieroni, A.; Sõukand, R.; Whitney, C.; Polesny, Z. Socio-Cultural Significance of Yerba Maté among Syrian Residents and Diaspora. Econ. Bot. 2021, 75, 97-111. [CrossRef]

21. Obón, C.; Rivera, D.; Alcaraz, F.; Attieh, L. Beverage and culture. "Zhourat", a multivariate analysis of the globalization of a herbal tea from the Middle East. Appetite 2014, 79, 1-10. [CrossRef]

22. Carmona, M.D.; Llorach, R.; Obon, C.; Rivera, D. "Zahraa", a Unani multicomponent herbal tea widely consumed in Syria: Components of drug mixtures and alleged medicinal properties. J. Ethnopharmacol. 2005, 102, 344-350. [CrossRef]

23. Marouf, M.; Batal, M.; Moledor, S.; Talhouk, S.N. Exploring the Practice of Traditional Wild Plant Collection in Lebanon. Food Cult. Soc. 2015, 18, 355-378. Available online: https://www.tandfonline.com/doi/full/10.1080/15528014.2015.1043103 (accessed on 28 November 2021). [CrossRef]

24. Marouf, M.L. Assessing the Current Use and Significance of Wild Edible Plants Traditionally Gathered in Lebanon: An Ethnobotanical Study. MSc thesis, American University of Beirut, Faculty of Agricultural and Food Sciences, Beirut, Lebanon. 2005. Available online: https:/ /idl-bnc-idrc.dspacedirect.org/handle/10625/38055 (accessed on 28 November 2021).

25. Della, A.; Paraskeva-Hadjichambi, D.; Hadjichambis, A.C. An ethnobotanical survey of wild edible plants of Paphos and Larnaca countryside of Cyprus. J. Ethnobiol. Ethnomedicine 2006, 2, 1-9. [CrossRef]

26. Pieroni, A.; Sõukand, R.; Amin, H.I.M.; Zahir, H.; Kukk, T. Celebrating multi-religious co-existence in Central Kurdistan: The bio-culturally diverse traditional gathering of wild vegetables among Yazidis, Assyrians, and Muslim Kurds. Hum. Ecol. 2018, 46, 217-227. [CrossRef]

27. Ali-Shtayeh, M.S.; Jamous, R.M.; Al-Shafie, J.H.; Wafa'A, E.; Kherfan, F.A.; Qarariah, K.H.; Isra'S, K.; Soos, I.M.; Musleh, A.A.; Isa, B.A.; et al. Traditional knowledge of wild edible plants used in Palestine (Northern West Bank): A comparative study. J. Ethnobiol. Ethnomed. 2008, 4, 1-13. [CrossRef]

28. Güneş, S.; Savran, A.; Paksoy, M.Y.; Çakılcığlu, U. Survey of wild food plants for human consumption in Karaisalı (AdanaTurkey). Indian J. Tradit. Knowl. 2018, 17, 290-298. Available online: http://nopr.niscair.res.in/handle/123456789/43649 (accessed on 28 November 2021).

29. Ministry of State for Environmental Affairs of Syria. The Fourth National Report on Biodiversity in the Syrian Arab Republic. 2009. Convention on Biological Diversity Web Site. Available online: https://www.cbd.int/doc/world/sy/sy-nr-04-en.pdf (accessed on 28 November 2021).

30. Estimate of the population in Syria by governorates 2016. 2016. Central Bureau of Statistics Web site. Available online: http:/ / cbssyr.sy/yearbook/2017/Data-Chapter2/TAB-4-2-2017.pdf (accessed on 28 November 2021).

31. Abou Zakhem, B.; Hafez, R. Environmental isotope study of seawater intrusion in the coastal aquifer (Syria). Environ. Geol. 2007, 51, 1329-1339. [CrossRef]

32. Markoe, G. People of the Past Phoenicians; University of California Press: Berkeley, CA, USA, 2000.

33. Qutrib, H.I. “Useful Syria” and Demographic Changes in Syria. 2016. King Faisal Center for Research and Islamic Studies Web Site. Available online: https:/ / www.kfcris.com/pdf/5e43a7813784133606d70cc8b52d433b5909a9623e8c2.pdf (accessed on 28 November 2021)

34. Tartous/ Factsheet/ End of Year 2017. 2017. The UN Refugee Agency Web Site. Available online: https://www.unhcr.org/sy/ wp-content/uploads/sites/3/2018/02/06-Tartous-FO-Factsheet-2017.pdf (accessed on 28 November 2021).

35. Population Status Assessment Survey 2014, Central Bureau of Statistics Web Site. 2014. Available online: http://cbssyr.sy (accessed on 28 November 2021). (In Arabic).

36. SYRIA-Review on the Impact of Rising Food Prices. 2020. World Food Programme Web Site. Available online: https:/ / docs.wfp.org/api/documents/WFP-0000113454/download/?_ga=2.141487922.1886618691.1612728751-1684190943.1 609703282\&_gac=1.162544078.1612728775.Cj0KCQiAvP6ABhCjARIsAH37rbSWEQ6oYKEQb5NC4Hzn7ijZNuOdfGtJYrikW2 1H3pfX0_YzCLqYR3kaAl2vEALw_wcB (accessed on 28 November 2021).

37. Ministry of Local Administration and Environment of Syria. The Fifth National Report to the Convention on Biological Diversity. 2016. Convention on Biological Diversity Web Site. Available online: https://www.cbd.int/doc/world/sy/sy-nr-05-ar.pdf (accessed on 28 November 2021). (In Arabic)

38. Syrian Arab Republic mVAM Bulletin Issue, No. 52: January and February 2021. 2021. World Food Programme Web Site. Available online: https:/ / docs.wfp.org/api/documents/WFP-0000124749/download/? ga=2.138057584.1391806201.1626620 016-1599089406.1626620016 (accessed on 28 November 2021).

39. Espinosa, M.M.; Bieski, I.G.C.; Martins, D.T.O. Sampling in Ethnobotanical Studies of Medicinal Plants. In Methods and Techniques in Ethnobiology and Ethnoecology; Albuquerque, U., Cruz da Cunha, L., de Lucena, R., Alves, R., Eds.; Springer: New York, NY, USA, 2014; pp. 197-212. [CrossRef]

40. Dolores, M.; Tongco, C. Purposive Sampling as a Tool for Informant Selection. Ethnobot. Res. Appl. 2007, 5, 147-158. 
41. Code of Ethics. 2008. ISE (International Society of Ethnobiology) Web Site. Available online: https://www.takiwasi.com/pdf/ declaraciones /isece-eng.pdf (accessed on 28 November 2021).

42. World Flora Online Home Page. Available online: http://www.worldfloraonline.org/ (accessed on 28 November 2021).

43. Pieroni, A.; Ahmed, H.M.; Zahir, H. The spring has arrived: Traditional wild vegetables gathered by Yarsanis (Ahl-e Haqq) and Sunni Muslims in Western Hawraman, SE Kurdistan (Iraq). Acta Soc. Bot. Pol. 2017, 86, 1. [CrossRef]

44. Ozcan, A.; Susluoglu, Z.; Nogay, G.; Ergun, M.; Sutyemez, M. Phytochemical characterization of some sumac (Rhus coriaria L.) genotypes from southern part of turkey. Food Chem. 2021, 358, 129779. [CrossRef]

45. Perović, J.; Šaponjac, V.T.; Kojić, J.; Krulj, J.; Moreno, D.A.; García-Viguera, C.; Bodroža-Solarov, M.; Ilić, N. Chicory (Cichorium intybus L.) as a food ingredient-Nutritional composition, bioactivity, safety, and health claims: A review. Food Chem. 2021, 336, 127676. [CrossRef]

46. Almanea, A.; Abd El-Aziz, G.S.; Ahmed, M.M.M. The potential gastrointestinal health benefits of Thymus vulgaris essential oil: A review. Biomed. Pharmacol. J. 2019, 12, 1793-1799. [CrossRef]

47. Bello, O.M.; Fasinu, P.S.; Bello, O.E.; Ogbesejana, A.B.; Adetunji, C.O.; Dada, A.O.; Ibitoye, O.S.; Aloko, S.; Oguntoye, O.S. Wild vegetable Rumex acetosa Linn.: Its ethnobotany, pharmacology and phytochemistry-A review. S. Afr. J. Bot. 2019, 125, 149-160. [CrossRef]

48. García-Herrera, P.; Morales, P.; Fernández-Ruiz, V.; Sánchez-Mata, M.C.; Cámara, M.; Carvalho, A.M.; Ferreira, I.C.; Pardode-Santayana, M.; Molina, M.; Tardío, J. Nutrients, phytochemicals and antioxidant activity in wild populations of Allium ampeloprasum L., a valuable underutilized vegetable. Food Res. Int. 2014, 62, 272-279. [CrossRef]

49. Farhan, H.; Malli, F.; Rammal, H.; Hijazi, A.; Bassal, A.; Ajouz, N.; Badran, B. Phytochemical screening and antioxidant activity of Lebanese Eryngium creticum L. Asian Pac. J. Trop. Biomed. 2012, 2, S1217-S1220. [CrossRef]

50. Matthäus, B.; Özcan, M.M. Chemical evaluation of flower bud and oils of tumbleweed (Gundelia tourneforti L.) as a new potential nutrition sources. J. Food Biochem. 2011, 35, 1257-1266. [CrossRef]

51. Hiçsönmez, Ü.; Ereeş, F.S.; Özdemir, C.; Özdemir, A.; Cam, S. Determination of major and minor elements in the Malva sylvestris L. from Turkey using ICP-OES techniques. Biol. Trace Elem. Res. 2009, 128, 248-257. [CrossRef]

52. Loizzo, M.R.; Menichini, F.; Conforti, F.; Tundis, R.; Bonesi, M.; Saab, A.M.; Statti, G.A.; de Cindio, B.; Houghton, P.J.; Menichini, F.; et al. Chemical analysis, antioxidant, antiinflammatory and anticholinesterase activities of Origanum ehrenbergii Boiss and Origanum syriacum L. essential oils. Food Chem. 2009, 117, 174-180. [CrossRef]

53. Imran, M.; Talpur, F.N.; Jan, M.I.; Khan, A.; Khan, I. Analysis of nutritional components of some wild edible plants. J. -Chem. Soc. Pak. 2007, 29, 500-508.

54. Ladeji, O.; Okoye, Z.S.; Waidu, Z. Effect of supplementation of laboratory chow with leaf of Rumex acetosa (sorrel) on body weight and serum levels of amino acids and minerals in rat. Food Chem. 1997, 59, 15-17. [CrossRef]

55. Tardío, J.; Pardo-de-Santayana, M. Cultural importance indices: A comparative analysis based on the useful wild plants of Southern Cantabria (Northern Spain). Econ. Bot. 2008, 62, 24-39. [CrossRef]

56. Mohieddin, A.A.; Khalil, A.K.; Abdullah, K.; Saleh, T. Preliminary Study and Phytochemical Screening of Arum dioscorides Sibth. in Syria. Int. J. Pharmacogn. Phytochem. Res. 2017, 9, 165-173. [CrossRef]

57. Shumsky, S.A.; Hickey, G.M.; Pelletier, B.; Johns, T. Understanding the contribution of wild edible plants to rural social-ecological resilience in semi-arid Kenya. Ecol. Soc. 2014, 19, 34. [CrossRef]

58. Harris, F.M.; Mohammed, S. Relying on nature: Wild foods in northern Nigeria. Ambio. 2003, 2, 24-29. [CrossRef]

59. Zinyama, L.M.; Matiza, T.; Campbell, D.J. The use of wild foods during periods of food shortage in rural Zimbabwe. Ecol. Food Nutr. 1990, 24, 251-265. [CrossRef]

60. Average Salary in Syria 2021. 2021. Salary Explorer Web Site. Available online: http:/ / www.salaryexplorer.com/salary-survey. php?loc=211\&loctype $=1$ (accessed on 28 November 2021).

61. Nutrition Interventions Syria 2017. 2017. World Food Programme Web Site. Available online: https://www.wfp.org/ publications/syria-regional-crisis-factsheets (accessed on 28 November 2021).

62. Rink, L. Zinc and the immune system. Proc. Nutr. Soc. 2000, 59, 541-552. [CrossRef] 